\title{
GNE genotype explains $20 \%$ of phenotypic variability in GNE myopathy
}

Oksana Pogoryelova, PhD,* Ian J. Wilson, PhD,* Hank Mansbach, MD, Zohar Argov, MD, Ichizo Nishino, PhD, and Hanns Lochmüller, MD

Neurol Genet 2019;5:e308. doi:10.1212/NXG.0000000000000308

\section{Abstract}

\section{Objective}

To test the hypothesis that common GNE mutations influence disease severity; using statistical analysis of patient cohorts from different countries.

\section{Methods}

Systematic literature review identified 11 articles reporting 759 patients. GNE registry data were used as a second data set. The relative contributions of the GNE mutations, homozygosity, and country to the age at onset were explored using linear modeling, and relative importance measures were calculated. The rate of ambulation loss for GNE mutations, homozygosity, country, and age at onset was analyzed using Cox proportional hazards models.

\section{Results}

A spectrum of symptoms and large variability of age at onset and nonambulatory status was observed within families and cohorts. We estimated that $20 \%$ of variability is explained by GNE mutations. Individuals harboring p.Asp207Val have an expected age at onset 8.0 (s.e1.0) years later than those without and probability of continued ambulation at age 40 of 0.98 (95\% confidence interval [CI] 0.96-1). In contrast, p.Leu539Ser results in onset on average 7.2 (s.e.2.7) years earlier than those without this mutation, and p.Val603Leu has a probability of continued ambulance of 0.61 (95\% CI 0.50-0.74) at age 40, but has a nonsignificant effect on age at onset.

\section{Conclusions}

GNE myopathy severity significantly varies in all cohorts, with $20 \%$ of variability explained by the GNE mutation. Atypical symptoms and clinical presentation suggest that physical and instrumental examination should include additional clinical tests. Proven and measurable effect of GNE mutations on the disease severity should be factored in patient management and clinical research study for a better data interpretation.
Correspondence

Dr. Pogoryelova

Oksana.pogoryelova@ncl.ac.uk

\footnotetext{
*Contributed equally to the study.
}

From the Institute of Genetic Medicine (O.P., I.J.W.), Newcastle University, Newcastle upon Tyne, United Kingdom; Ultragenyx Pharmaceutical (H.M.), CA; Department of Neurology (Z.A.), Hadassah-Hebrew University Medical Center, Jerusalem, Israel; Department of Neuromuscular Research (I.N.), National Institute of Neuroscience, National Center of Neurology and Psychiatry, Tokyo, Japan; Department of Neuropediatrics and Muscle Disorders (H.L.), Medical Center-University of Freiburg, Faculty of Medicine, Freiburg, Germany; Centro Nacional de Análisis Genómico (CNAG-CRG) (H.L.), Center for Genomic Regulation, Barcelona Institute of Science and Technology (BIST), Barcelona, Catalonia, Spain; and Children's Hospital of Eastern Ontario Research Institute (H.L.), University of Ottawa, Ottawa, Canada and Division of Neurology, Department of Medicine, The Ottawa Hospital, Ottawa, Canada.

Supported by TREAT-NMD operating grants, FP6 LSHM-CT-2006-036825, 20123307 UNEW FY2013, and AFM 16104. Further support came from the European Union Seventh Framework Programme (FP7/2007-2013) under grant agreement No. 305444 (RD-Connect) and Medical Research Council, UK (reference G1002274, grant ID 98482).

Funding information and disclosures are provided at the end of the article. Full disclosure form information provided by the authors is available with the full text of this article at Neurology.org/NG.

The Article Processing Charge was funded by the RCUK.

This is an open access article distributed under the terms of the Creative Commons Attribution License 4.0 (CC BY), which permits unrestricted use, distribution, and reproduction in any medium, provided the original work is properly cited. 


\section{Glossary}

$\mathbf{C I}=$ confidence interval; Ace-ER $=\mathrm{N}$-acetylneuraminic acid extended release; AIC $=$ Akaike Information Criterion.

GNE myopathy is an autosomal recessive rare distal myopathy. It is a slow progressing disease caused by mutations in the GNE gene, which affects sialic acid synthesis. Clinical course varies from mild to severely debilitating forms leading to end-stage skeletal muscle weakness. The genetic basis for GNE myopathy was established in $2001{ }^{1}{ }^{1}$ more than 180 mutations are currently known, among them several founder or recurrent mutations. ${ }^{2-7}$ Wide phenotypic variability is described in the literature, even within families carrying the same mutation. Some unique features of GNE myopathy are observed only in certain populations. ${ }^{8,9}$ Population-based studies suggest that GNE genotype may influence predisposition to a faster or slower progression of the disease, but were often not large enough to reach statistical significance. ${ }^{5,6,10}$ Molecular mechanisms underlying muscle weakness have been studied in cell and enzyme studies, suggesting that different missense mutations may affect enzymatic activity to a different extent. Primary muscle cells with GNE mutations showed a significant reduction in sialic acid levels, ${ }^{11}$ suggesting that this might be the cause of the muscle weakness. A defined link between GNE genotype and phenotype would have a major impact on the clinical trial planning and routine disease management and care. The aim of the study is to explore cohort-based studies to test the hypothesis that GNE genotype influences GNE myopathy disease severity.

\section{Methods}

\section{Literature review}

PubMed database search was conducted on 12 May 2017 using search words "GNE myopathy," "HIBM," "quadriceps sparing myopathy," "distal myopathy with rimmed vacuoles." In total, 494 records were identified. Duplicated records, single case reports, and scientific publication based on molecular studies, cells, and animal models were eliminated. Other records were checked for the following: cohort size $\geq 15$ patients, availability of demographic and clinical description, and description of the GNE mutations in the cohort. Eleven articles were selected for analysis (total 759 cases, table 1). Seven articles contained per patient data (UK, India, Bulgaria, Iran, China 1, China 2, and Japan 3) and 4 articles (Israel, Japan 1, Japan 2, and Japan 4) provided cohort summary information. In total, $\mathrm{n}=360$ patients had individual level data, $\mathrm{n}=342$ with defined age at onset, and $\mathrm{n}=247$ with known ambulation status.

\section{Registry data}

GNE myopathy registry (previously described ${ }^{12}$ ) was used as another independent data set. The registry data were interrogated for number of patients per country (subset A) and for patients with homozygous mutations regardless of their country of residence (subset B). Six countries were presented by $\geq 14$ patients (total $\mathrm{n}=135$ ). Four GNE mutations were present in the homozygous state $\geq 3$ patients (total $n=31$ ). The study received approval from Newcastle and North Tyneside 1 Research Ethics Committee, reference number $13 / \mathrm{NE} / 0123$. Informed consent was obtained from all patients participating in the registry.

\section{Statistical modeling of age at onset}

Individuals with known genotype and known age at onset were selected for this analysis $(n=342)$. Those variants with at least 10 observations in the data set were used for further analysis. Ten mutations (table 2) were $77 \%$ of the total changes in the data. Genetic explanatory variables were constructed for each mutation under a dominance model, where the variable is coded for the presence/absence of a mutation and allelic dosage model that gives the allele count $(0,1$, or 2$)$ for the 10 changes. Other explanatory variables used were the geographic location of the study and whether an individual was homozygous. A series of linear models were fitted for the age at onset regressed against all combinations of location and/or homozygosity and modeling the genetic contribution as either allelic dose or dominance models using the $\mathrm{R}$ statistical package. ${ }^{13}$

Selection of the better fitting models was done using the stepwise regression with model choice made using the Akaike Information Criterion (AIC). ${ }^{14}$ The relative importance of the different factors in explaining variation in the age at onset was assessed using the relaimpo package within $\mathrm{R}^{15}$ The best fitting models were then used to predict the age at onset for individuals in the GNE registry.

\section{Age of ambulation loss}

Individuals in the onset data that had information about ambulation status, either continued ambulation at assessment or the age at loss of ambulation $(n=220)$, were used for analysis of ambulation status. Mutations with more than 10 observations in the data set were used for further analysis $(\mathrm{n}=$ 6 mutations, table 2). Cox proportional hazards models ${ }^{16}$ were used to evaluate the relationship of continued ambulation to the genotype data, as described above, the study, and the age at onset. Initially univariate survival models were fitted and a threshold $p$ value of 0.1 was used to select those variables to consider in a multivariate analysis. A multivariate model was chosen from the best combination of significant univariate models. Choices between non-nested models were made using the AIC. Model fit was assessed using survival concordance for registry individuals.

\section{Data availability statement}

The study analyzes published data. Anonymized GNE registry data can be shared upon request to the GNE Registry Steering Committee. 


\begin{tabular}{|c|c|c|c|c|c|c|c|c|c|c|}
\hline $\begin{array}{l}\text { Country, } \\
\text { where the } \\
\text { study was } \\
\text { conducted }\end{array}$ & $\begin{array}{l}\text { Ethnical } \\
\text { background }\end{array}$ & $\begin{array}{l}\text { Number } \\
\text { of } \\
\text { patients }\end{array}$ & $\begin{array}{l}\text { Percentage } \\
\text { of male/ } \\
\text { female ratio } \\
\text { (n) }\end{array}$ & $\begin{array}{l}\text { Age at } \\
\text { baseline, } \\
\text { mean }( \pm S D)\end{array}$ & $\begin{array}{l}\text { Mean age at } \\
\text { onset }( \pm S D) ; \\
\text { [range] }\end{array}$ & $\begin{array}{l}\text { Percentage of } \\
\text { nonambulant } \\
\text { patients }(n)\end{array}$ & $\begin{array}{l}\text { Mean age at } \\
\text { non } \\
\text { ambulatory } \\
\text { state }( \pm \text { SD) }\end{array}$ & $\begin{array}{l}\text { GNE genetics } \\
\text { description of the } \\
\text { cohort }\end{array}$ & $\begin{array}{l}\text { Cardiac } \\
\text { involvement }\end{array}$ & $\begin{array}{l}\text { Respiratory } \\
\text { involvement }\end{array}$ \\
\hline Japan $1^{9}$ & Japanese & 121 & $45.5(55 / 66)$ & & $27.7(9.6)$ & $43.0(52)$ & $\begin{array}{l}35.4(11.3) ; \\
\text { mean } 21.1 \mathrm{y} \\
\text { after the onset }\end{array}$ & $\begin{array}{l}\text { p.V603.L and p.D207V } \\
\text { account for } 71.0 \% \text { of } \\
\text { cases }\end{array}$ & $\begin{array}{l}\text { Normal in all tested } \\
\text { patients }(28.9 \%)\end{array}$ & $\begin{array}{l}\text { FVC normal }(33 \%), \\
\text { decreased in } 67 \% \\
\text { patients }\end{array}$ \\
\hline Japan $2^{17}$ & Japanese & 27 & $33.3(9 / 18)$ & $43.0(12.9)$ & $\begin{array}{l}25.9(10.3) ; \\
{[15-58]}\end{array}$ & $36.0(9)$ & Not available & $\begin{array}{l}\text { p.V603.L and p.D207V } \\
\text { account for } 75.0 \% \text { of all } \\
\text { mutations }\end{array}$ & $\begin{array}{l}\text { Structural and } \\
\text { rhythm } \\
\text { abnormalities in } \\
29.6 \% \text { patients. }\end{array}$ & $\begin{array}{l}\text { OSAS }^{a}(n=2), \text { FVC } \\
\text { drop }-3.3 \% \text { in } 1 \mathrm{y} \text { in } \\
\text { nonambulant subset }\end{array}$ \\
\hline Japan $3^{24}$ & Japanese & 212 & $44.8(95 / 117)$ & $41.6(14.1)$ & $\begin{array}{l}28.4 \text { SD10.2[10- } \\
61]\end{array}$ & $23.4(154)$ & $\begin{array}{l}36.8(11.3) ; \\
\text { [range 19-78] }\end{array}$ & $\begin{array}{l}\text { p.V603.L and p.D207V } \\
\text { account for } 88.7 \% \text { all } \\
\text { mutations }\end{array}$ & Not available & Not available \\
\hline Japan $4^{25}$ & Japanese & 71 & $33.8(24 / 44)$ & $43.1(13.0)$ & $\begin{array}{l}24.8 \text { SD } 8.3[12- \\
58]\end{array}$ & $\begin{array}{l}52.0(37) \\
{[50-80 \%]}\end{array}$ & $\begin{array}{l}34.9(11.7) ; \\
\text { [range 18-70] } \\
\text { Mean 17.0 (2.1) } \\
\text { y after the onset }\end{array}$ & $\begin{array}{l}\text { p.V603.L and p.D207v. } \\
86.2 \% \text { of all mutations }\end{array}$ & Not available & Not available \\
\hline Bulgaria $^{5}$ & Roma people & 50 & $62.0(31 / 19)$ & Not available & $\begin{array}{l}24.4(6.31) \\
{[10-42]}\end{array}$ & $64.0(32)$ & $\begin{array}{l}\text { Not available; } \\
\text { mean } 10.34 \\
(4.31) \text { y after } \\
\text { onset }\end{array}$ & $\begin{array}{l}\text { p. } 1618 \mathrm{~T} \text { account for } 98 \% \\
\text { of all mutations }\end{array}$ & $\begin{array}{l}\text { Structural and } \\
\text { rhythm } \\
\text { abnormalities in } \\
45.5 \% \text { patients }\end{array}$ & FVC [range 60-75\%] \\
\hline$\overline{U^{7}}$ & $\begin{array}{l}\text { White British, } \\
\text { Irish, Indian, } \\
\text { Pakistan }\end{array}$ & 26 & $53.9(14 / 12)$ & 47.7 & 30 (9.2); [10-44] & $19.2(5)$ & $46.3(8.0)$ & $\begin{array}{l}\text { p.A662V and p.D409Y } \\
\text { account for } 63 \%\end{array}$ & $\begin{array}{l}\text { Mild systolic } \\
\text { dysfunction- } 1 \\
\text { patient }\end{array}$ & Normal in all patients \\
\hline |srael $^{4}$ & $\begin{array}{l}\text { Middle Eastern } \\
\text { Jews, Karaites, } \\
\text { Arabs }\end{array}$ & 129 & Not available & Not available & {$[17-48]$} & Not available & $\begin{array}{l}\text { Not available; } \\
>15 \text { y since } \\
\text { onset }\end{array}$ & $\begin{array}{l}\text { p.M743T accounts for } \\
100 \% \text { of all mutations }\end{array}$ & None & Not available \\
\hline $\operatorname{Iran}^{10}$ & $\begin{array}{l}\text { Iranian non- } \\
\text { Jewish (Muslim } \\
\text { Persian) }\end{array}$ & 18 & $50.0(9 / 9)$ & $\begin{array}{l}34 \text { [range } \\
24-47]\end{array}$ & $25.7[19-31]$ & $16.7(3)$ & $\begin{array}{l}37.3 ; 13-15 y \\
\text { since onset }\end{array}$ & $\begin{array}{l}\text { High prevalence of } \\
\text { p.M743T. }\end{array}$ & $\begin{array}{l}\text { Normal in all } \\
\text { patients }\end{array}$ & Normal in all patients \\
\hline China $1^{6}$ & Chinese & 35 & $45.7(16 / 19)$ & $\begin{array}{l}37.3(10.2) \\
\text { [range 22-66] }\end{array}$ & $\begin{array}{l}30.6(7.3) \\
{[20-43]}\end{array}$ & Not available & Not available & $\begin{array}{l}\text { p.D207V allele } \\
\text { frequency in the cohort } \\
\text { of } 35.7 \%\end{array}$ & Not available & Not available \\
\hline China $2^{26}$ & Chinese & 53 & $50.9(27 / 26)$ & $\begin{array}{l}31.5(8.4) \text { [range } \\
11-46]\end{array}$ & $20.5(8.1)$ [5-39] & Not available & Not available & $\begin{array}{l}\text { No single dominating } \\
\text { mutation in the study } \\
\text { cohort }\end{array}$ & Not available & Not available \\
\hline India $^{8}$ & Indians & 17 & $70.6(12 / 5)$ & $\begin{array}{l}34.1(7.1) \text { [range } \\
25-49]\end{array}$ & $\begin{array}{l}27.0(6.3) \\
{[21-46]}\end{array}$ & $5.9(1)$ & Not available & $\begin{array}{l}\text { 76.5\% patients harbour } \\
\text { p.V727M }\end{array}$ & Not available & Not available \\
\hline
\end{tabular}


Table 2: Genomic positions and amino acid changes for the 10 changes analyzed in the onset data

\begin{tabular}{|c|c|c|c|c|c|c|c|c|c|}
\hline $\begin{array}{l}\text { Genomic } \\
\text { position }\end{array}$ & $\begin{array}{l}\text { Amino acid } \\
\text { change }\end{array}$ & Ref SNP ID & $\begin{array}{l}\text { Frequency } \\
\text { in onset } \\
\text { data }\end{array}$ & $\begin{array}{l}\text { Populations } \\
\text { present }\end{array}$ & $\begin{array}{l}\text { Count } \\
\text { in } \\
\text { ExAC }\end{array}$ & $\begin{array}{l}\text { Count in } \\
1000 \\
\text { genomes }\end{array}$ & $\begin{array}{l}\text { Frequency } \\
\text { ambulation } \\
\text { data }\end{array}$ & $\begin{array}{l}\text { Estimated } \\
\text { change in } \\
\text { age at } \\
\text { onset }\end{array}$ & $\begin{array}{l}\text { Estimated } \\
\text { hazard for } \\
\text { model amb2 } \\
(95 \% \mathrm{Cl})\end{array}$ \\
\hline 36219937 & p.Val603Leu & rs121908632 & 0.29 & 2 & 3 & 1 & 0.34 & & $3.1(1.5-6.3)$ \\
\hline 36246117 & p.Asp207Val & rs139425890 & 0.17 & 2 & 5 & 2 & 0.15 & $8.0(6.1,9.9)$ & $0.12(0.03-0.5)$ \\
\hline 36219891 & p.ILe618Thr & & 0.16 & 4 & 1 & 0 & 0.23 & & $1.9(0.96-3.9)$ \\
\hline 36218221 & p.Ala631Val & rs62541771 & 0.047 & 3 & 10 & 0 & $(0.002)$ & $4.8(1.2,8.5)$ & \\
\hline 36217396 & p.Met743Leu & rs28937594 & 0.033 & 2 & 4 & 0 & 0.043 & & \\
\hline 36249315 & p.Cys44Ser & & 0.027 & 2 & 0 & 0 & $(0.007)$ & & \\
\hline 36236861 & p.Arg277Trp & rs121908629 & 0.020 & 4 & 0 & 0 & 0.025 & & \\
\hline 36236887 & p.Leu268Leu & & 0.018 & 1 & 0 & 0 & 0.027 & & \\
\hline 36227394 & p.Asp409Tyr & rs199877522 & 0.017 & 1 & 14 & 0 & (0) & & \\
\hline 36222884 & p.Leu539Ser & & 0.015 & 1 & 0 & 0 & (0) & $\begin{array}{l}-7.2(-12.7,- \\
1.8)\end{array}$ & \\
\hline
\end{tabular}

All genomic positions are on chromosome 9 and based on amino acid changes mapped to transcript ENST00000377902. Changes with bracketed frequencies in the ambulation data were not included in the ambulation model.

\section{Results}

\section{Age at onset}

Eleven cohorts were selected for analysis. Four publications from Japan met the inclusion criteria and may have overlapping patients. Two publications from China may have overlapping patients, but this is unlikely. The overlap in patient populations between those cohorts cannot be determined; therefore, they were analyzed as individual patient cohorts. Bulgaria, UK, Israel, Iran, and India are presented by a single publication (table 1).

Number of patients in populations varied between 17 (India) and 212 (Japan). Average age at baseline varied between 31.5 years (China) and 47.7 years (UK). The earliest onset at 10 years was detected in Japan, UK, and Bulgaria, while the latest onset was observed at 61 years in Japan, giving Japan the largest variability of age at onset (figure 1).

Linear models were fitted to the age at onset on those individuals with information about genotype and age at onset $(\mathrm{n}=$ 341). Genetic variables provided a better fit to the data than location and homozygosity (maximum adjusted $\mathrm{r}^{2}$ was 0.08 without individual mutation explanatory variables). Models using allelic dose models were marginally worse than dominance models. Statistically significant mutations were p.Asp207Val (increase in age at onset of 8 years $p=9 \mathrm{e}-16$ ), p.Ala631Val (increase of 4.8 years, $p=0.002$ ), and p.Leu539Ser (decrease of 7.2 years, $p=0.008$ ). Confidence intervals are given in table 2 . The proportion of variability explained by these 3 genetic factors was estimated to be $18.8 \%$, using the reliampo package. For univariate models, the age at onset was a highly significant predictor of continued ambulance $(p<2 \mathrm{e}-16)$, along with individual homozygosity $(p=7 \mathrm{e}-16)$, and the mutations, p.Val603Leu $(p=0.007)$, p.Asp207Val $(p=0.0002)$, and p.ILe618Thr $(p=3.4 \mathrm{e}-14)$. In a multivariate model using all variables homozygosity was only marginally significant $(p>0.01)$. Age at onset and dominance for the 3 mutations - the change in hazard for the 3 mutations - was used in the final model (table 2). The effect of the age at onset and the 3 mutations (figure 2). We can show the effects of the 3 mutations by comparing mutations to an individual with onset at age 30 and without any of the 3 mutations who has a probability of 0.85 (95\% confidence interval [CI] 0.77-0.94) of continued ambulance at age 40 .

\section{Age of ambulation}

Lowest proportion of nonambulant patients was described in India (5.9\%) and the highest in Bulgaria (64.0\%), resulting in almost every third GNE patient in the world being nonambulant (32.5\%). Authors, of the selected manuscripts, described reaching nonambulatory status in 2 ways: (1) Age at nonambulatory status (5 publications) and duration (i.e., years) since the onset to nonambulatory status (3 publications). The former shows that patients reach nonambulatory status at an average 38.1 years old, with over a decade (11.4 years) difference between "Japan 4" and UK cohorts. The latter shows that the progress since onset to the wheelchair bound state can take between 10.3 and 21.1 years with an average of 16.2 years.

A mutation at p.Val603Leu gives a probability of ambulance at age 40 of 0.61 (95\% CI $0.49-0.74)$, a mutation at p.IleThr gives 0.73 (95\% CI 0.163-0.83), and a mutation at p.Asp207Val has a probability of continued ambulance of 0.98 
Figure 1 Forest plot showing data overview by onset on a cohort level

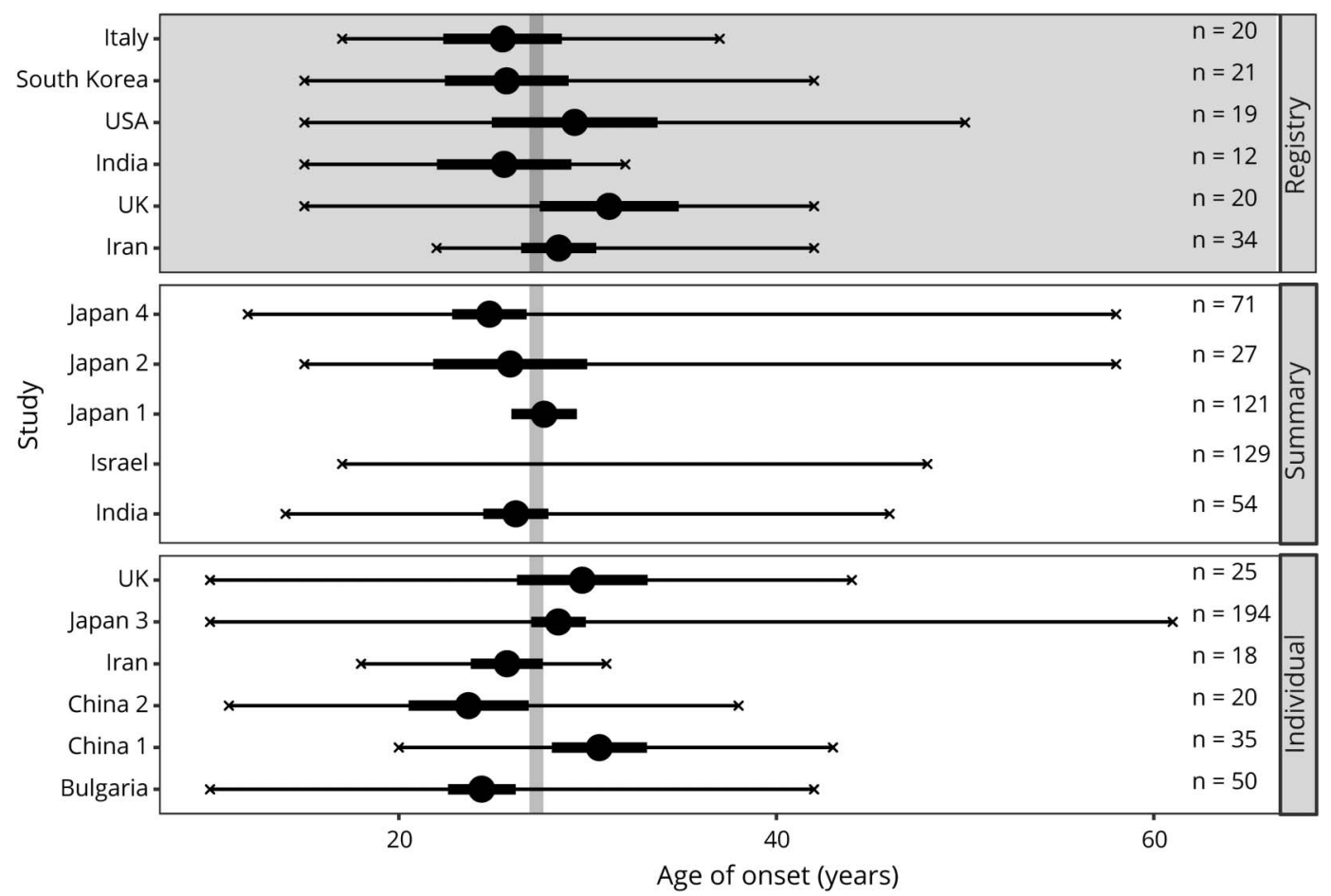

Studies are grouped by source, individual level data (bottom panel), summary statistics form articles (middle panel), and by country from the registry (top panel with dark background). Means are given by large circles, the confidence intervals by thick black lines, and the minimum and maximum values by $\mathrm{x}$. Sample sizes for each study are indicated to the right. The overall mean (calculated from individual level data) is shown by the vertical grey line. Student- $t$ confidence intervals were calculated for registry countries and individual studies. Confidence intervals for summary studies were taken from the articles.

(95\% CI 0.96-1). When considering only the Japanese cohort, we confirm that the presence of p.Asp207Val is associated with a much milder phenotype (probability of ambulance at age 40 is $0.9895 \% \mathrm{CI}[0.94-1.0]$ ), compared to individuals with no copies probability $0.58[0.45,0.73]$. Homozygotes of p.Val603Leu have a much more severe phenotype with probability of continued ambulance of $0.3995 \% \mathrm{CI}$ [0.24-0.61] compared to a heterozygote, probability 0.90 95\% CI [0.80-1.0].

\section{Genotypes}

Founder or high-prevalence mutations were significantly prevalent in 9 cohorts. In 2 populations (Israel and Bulgaria), founder mutation appears in nearly all patients in homozygous state. Japan and UK showed 2 mutations dominating the cohorts. China 1 and China 2 cohorts showed a different spectrum of mutations with one dominating mutation in former study and multiple mutations without clear dominance in the latter.

\section{Cardiorespiratory function}

It is considered that GNE myopathy does not increase the risk of cardiomyopathy and respiratory failure. However, a 1 yearlong natural history study conducted in Japan showed that forced vital capacity (FVC) declines in nonambulatory patients. ${ }^{17}$ Description of the respiratory function was available in 5 of 10 studies. UK and Iran described it as "normal in all patients." FVC was either normal or mildly to moderately decreased in all other tested patients. No severe decline in FVC was reported. Cardiomyopathy was not reported; nevertheless, some structural and rhythm abnormalities were present in 29.6 and $45.5 \%$ of patients from "Japan 2" and Bulgaria, respectively. Reported abnormalities included borderline reduction in ejection fraction and impaired relaxation (in patients who had concomitant diseases such as diabetes or hypertension). ECG in a few patients showed evidence of abnormal repolarization and left ventricular hypertrophy. Rhythm abnormalities such as extrasystolic arrhythmia and borderline nonspecific intraventricular delay were observed on a few occasions. Sudden death of unknown cause was reported in 4 nonambulant patients without a family history of cardiac rhythm abnormalities. ${ }^{5}$

\section{Atypical features}

Muscle biopsy appearance without rimmed vacuoles was observed in the UK and Japan and is likely to be linked to the site of the biopsy (i.e., quadriceps as the least affected muscle) or early stage of the disease. Thrombocytopenia was reported in 2 Japanese cohorts ("Japan 1" and "Japan 2"). A high rate of an early onset presentation ( $<20$ years) was reported in "Japan 4" cohort. Asymmetrical weakness was evident in the UK and both Chinese cohorts. Quadriceps sparing, almost a pathognomonic feature of GNE myopathy, was absent in a small number of patients from Israel, China 1, and China 2 cohorts. Facial and neck weakness and limb-girdle muscle weakness at early stages of the disease were observed in China and Israel. 

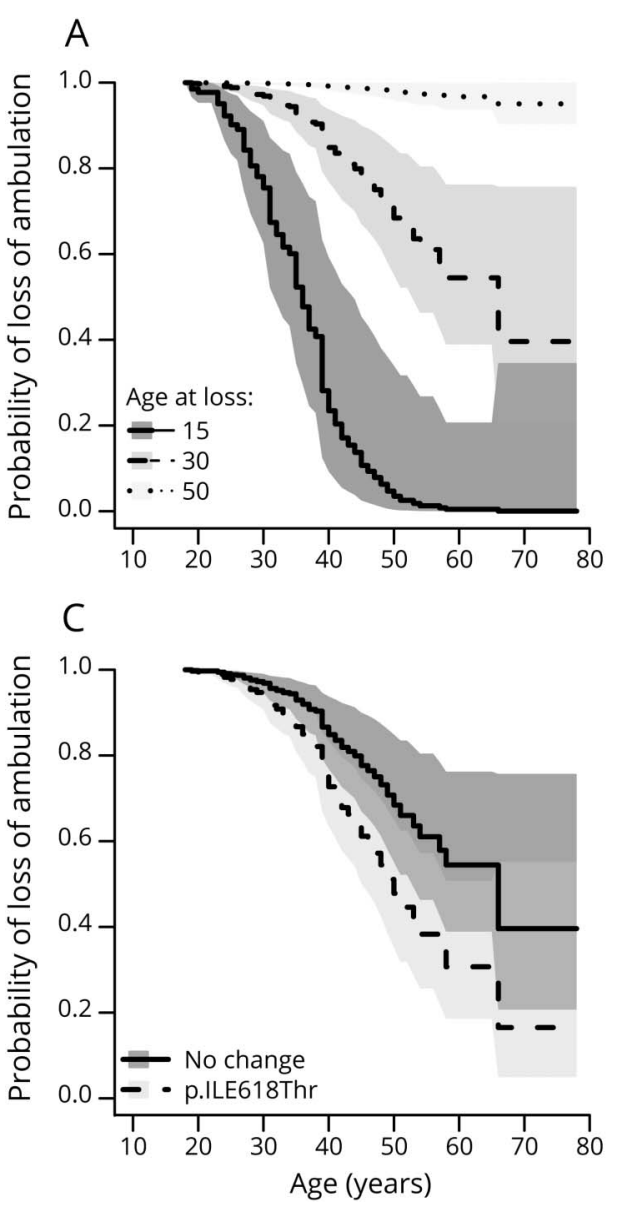

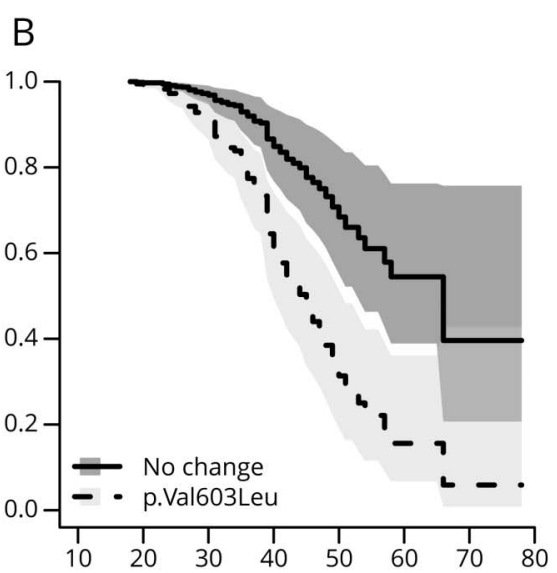

D

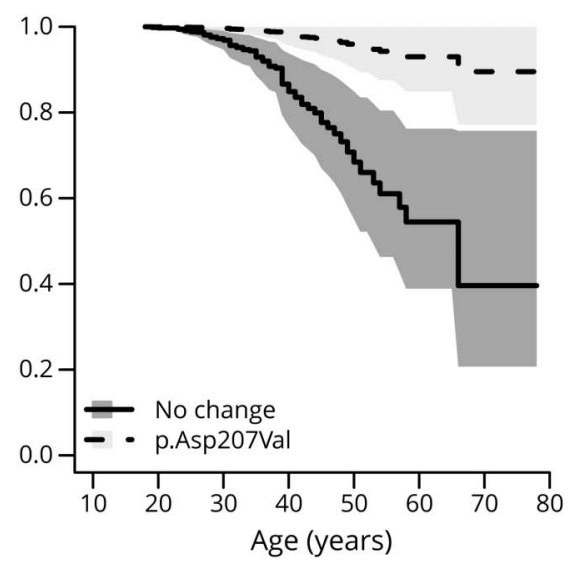

(A) shows fitted values for model 2 with age, for an individual without p.Val603Leu, p.lle618Thr, or p.Asp207Val. (B, C and D) give expected curves for an individual with and without the given mutation, with shaded areas indicating $90 \%$ confidence intervals.

\section{Analysis of the registry cohort}

Age at onset and nonambulatory status were compared between 6 country-specific cohorts, with $\mathrm{n} \geq 14$ patients. Baseline data are presented in table 3 . Using the model and parameter values estimated in from section 6 to predict onset times for the registry data $(n=126)$ was not fully successful, with an $r^{2}$ of 0.04 between the self-reported onset values in the registry data and the onset values predicted from this model based on the registry genetic data. So, there is a relationship between estimated onset time and predicted time, but this is not as strong as in the meta data set.

Registry data with ambulance data had a sample size of 113 . Survival concordance for registry individuals was calculated using the parameters from the best fit survival model. This works on pairs of individuals and averages how often the individual with the lowest ambulance time also has the highest risk score. This is then averaged over all pairs of individuals. Hence, perfect matches would have a concordance of 1 and a model that was random would have a concordance of 0.5 . The concordance for the registry data was 0.78 , which shows good agreement.

Registry data were also interrogated to identify homozygous patients irrespectively of their country of residence. Four subsets with the number of patients $\geq 4$ were analyzed. Because of a small number of available data, we present it only for descriptive analysis. Baseline demographic data, genotype, and clinical parameters are presented in table 3 .

\section{Discussion}

Disease severity and variability in its presentation are factors to consider in the disease management and planning clinical research. Patients are keen to know their prognosis and likely trajectory of progression to make personal choices. Rare disease status leads to scarcity of the data and availability of biological samples to study. Therefore, an integrated analysis of the available data provides an additional insight in understanding the correlation between GNE genotype and phenotype.

Cohort-based studies provided country-specific data. Analysis of these cohorts showed the presence of outliers with an early or late onset of the first symptoms in every cohort, which is not explained by a particular mutation. We find that almost $20 \%$ of the variability in age at onset is due to the GNE genotype, with the change to p.Asp207Val being associated with on average an 8-year increase in age at onset. In contrast, p.Leu539Ser results in onset on average 7.2 years earlier than those without this mutation. 
Table 3 Analysis of the registry data

\begin{tabular}{|c|c|c|c|c|c|c|c|c|}
\hline $\begin{array}{l}\text { Country, } \\
\text { of } \\
\text { residence }\end{array}$ & $\begin{array}{l}\text { Ethnicity of } \\
\text { the study } \\
\text { cohort }\end{array}$ & $\begin{array}{l}\text { Number } \\
\text { of } \\
\text { patients }\end{array}$ & $\begin{array}{l}\text { Male/ } \\
\text { female } \\
\text { ratio \% (n/ } \\
\text { n) }\end{array}$ & $\begin{array}{l}\text { Age at } \\
\text { baseline, } \\
\text { mean } \\
( \pm S D)\end{array}$ & $\begin{array}{l}\text { Mean age } \\
\text { at onset } \\
( \pm S D)\end{array}$ & $\begin{array}{l}\text { Percentage of } \\
\text { nonambulant } \\
\text { patients }(n)\end{array}$ & $\begin{array}{l}\text { Mean age at } \\
\text { nonambulatory } \\
\text { state }( \pm S D)\end{array}$ & Mutation description \\
\hline India & Asian & 14 & $57.1(8 / 6)$ & $34.1(8.2)$ & $25.6(5.6)$ & $7.7(1)$ & $\mathrm{n} / \mathrm{a}$ & $\begin{array}{l}14 \text { different mutations in } \\
\text { total; p.Val727Met is the } \\
\text { most common } \\
\text { accounting for } 42.3 \% \text { of } \\
\text { all mutations }\end{array}$ \\
\hline Italy & White & 20 & $40.0(8 / 12)$ & $39.7(11.6)$ & $25.5(6.7)$ & $40.0(8)$ & $35.9(9.7)$ & $\begin{array}{l}9 \text { mutations in total; } \\
\text { p.Asn550Ser and } \\
\text { p.Met743Thr are the most } \\
\text { common accounting for } \\
21.4 \% \text { of all mutations } \\
\text { each }\end{array}$ \\
\hline $\begin{array}{l}\text { South } \\
\text { Korea }\end{array}$ & Asian & 22 & $45.5(10 / 12)$ & $34.2(8.6)$ & $25.7(7.2)$ & $33.3(7)$ & $33.4(8.0)$ & $\begin{array}{l}5 \text { mutations in total; } 2 \\
\text { most common mutations } \\
\text { p.Val603Leu and } \\
\text { p.Cys44Ser accounting for } \\
50 \% \text { and } 38.5 \% \text { of all } \\
\text { mutations, respectively }\end{array}$ \\
\hline USA & $\begin{array}{l}\text { 85\% White, } \\
\text { 15\% Asian }\end{array}$ & 21 & $52.4(11 / 10)$ & $47.3(12.5)$ & $29.3(9.1)$ & $20.0(4)$ & $43.3(7.5)$ & $\begin{array}{l}11 \text { mutations in total; } 3 \\
\text { most common } \\
\text { p.Ala662Val, p.Val727Met, } \\
\text { and p.Met743Thr account } \\
\text { for } 21.4 \%, 14.3 \% \text {, and } \\
14.3 \% \text {, respectively, of all } \\
\text { mutations }\end{array}$ \\
\hline UK & $\begin{array}{l}\text { 76.2\% White, } \\
23.8 \% \text { Asian }\end{array}$ & 21 & $42.9(9 / 12)$ & $47.9(10.3)$ & $31.2(7.9)$ & $23.8(5)$ & $42.6(11.6)$ & $\begin{array}{l}9 \text { mutations in total; } 2 \\
\text { most common } \\
\text { p.Asp409Tyr and } \\
\text { p.Ala662Val account for } \\
25.0 \% \text { and } 45.0 \% \text { of all } \\
\text { mutations, respectively }\end{array}$ \\
\hline Iran & Asian & 37 & $48.6(18 / 19)$ & $36.3(8.0)$ & $28.7(5.7)$ & $9.4(3)$ & $38.7(5.8)$ & $\begin{array}{l}9 \text { mutations in total; one } \\
\text { most common } \\
\text { p.Met743Thr accounts for } \\
53.6 \% \text { of all mutations }\end{array}$ \\
\hline $\begin{array}{l}\text { Grand } \\
\text { total }\end{array}$ & & 135 & $47.4(64 / 71)$ & $39.4(11.0)$ & $27.8(7.2)$ & $21.5(28)$ & $38.9(9.2)$ & \\
\hline
\end{tabular}

Escherichia coli and insect cell disease models showed that epimerase and kinase enzymatic activity significantly varied among selected mutations. ${ }^{18}$ Slow progression of the disease may partially be explained by mitochondrial alterations. ${ }^{19}$ However, the correlation between the mutations and level of membrane sialylation is not consistent, which may indicate that involvement of other factors affecting the cellular and clinical phenotype. ${ }^{20}$ An indirect marker of disease severityage of nonambulation status, has a marked variability. ${ }^{12}$ The differences between age at nonambulatory status were associated with the age at onset and 3 founder mutations. While it is difficult to disentangle population effects from genetic effects, special fitting models for nonambulatory age were better fitted to genetic data than to population source, and these models showed good concordance with those used to predict continued ambulance in the GNE registry. Significant difference between Japan, Iran, and Bulgaria in age at nonambulatory status and proportion of nonambulant patients in the cohorts also point to the fact that the speed at which the disease progresses may be attributable to the founder mutations highly prevalent in those populations. When comparisons are made only with homozygous Japanese populations, the differences in survival curves almost disappear. Roma people founder mutation (p.ILe618Thr) shows no evidence of association with the age at onset, but is associated with a lower age of loss of ambulation. The mutation p.Leu539Ser, only seen in the Chinese data, is associated with an onset 7.2 years earlier but is not seen in the ambulation data, and we cannot make any inferences about its impact on ambulation. As these mutations are not shared with other study populations, it is difficult to extract the effects of genotype. The differences in health care approaches can also potentially play a role in preserving ambulation.

Cohorts with a higher number of nonambulant patients also have a higher number of patients with compromised respiratory function. This confirms previous observation on a multinational level that respiratory function is normally preserved until the very nonambulatory stages of the disease. We also did not observe a correlation between cardiomyopathy and 
GNE myopathy but a number of mild-to-moderate structural and rhythm heart abnormalities were observed.

Rare symptoms found only in one country (e.g., thrombocytopenia or Beevor sign) could be attributable to the described ethnic groups only or to observational bias due to the differences in medical practices across the world. A new GNE mutation has been found to cause a congenital macrothrombocytopenia without noticeable muscle weakness to date. ${ }^{21}$ It supports the observation that platelet count may be compromised in GNE myopathy and therefore it may be recommended to include platelet count test in the routine management of the disease.

Spectrum of the disease presentation, severity, and specific features is important in planning clinical trials for adequate patient stratification and reduced bias due to known covariances. $\mathrm{N}$-acetylneuraminic acid extended release (Ace-ER) phase 2 and 3 clinical trials showed different results, where phase 2 showed that Ace-ER stabilizes the disease progression and causes statistical significant difference between treatment and placebo groups. $^{22}$ However, phase 3 showed no benefit of Ace-ER on muscle strength. ${ }^{23}$ We speculate that difference in the results between 2 studies could partially be accounted for differences in the study cohorts. In phase 2 trial, sites were located in 2 countries, the United States and Israel, where p.Met743Thr is most common. Phase 3 study enrolled a larger number of patients from 7 countries, with 4 of them being in Europe and one in Canada-where p.Met743Thr is much less prevalent. This genotype difference in the cohorts could have potentially had an impact on the discrepancy in the study results. We therefore suggest that GNE mutation should be taken in consideration as a factor for patient stratification in the clinical trials.

This article is a first attempt to look at the genotypephenotype correlation in GNE myopathy through a systematic review and meta-analysis. The analysis shows that GNE genotype has an impact on the phenotype and accounts for $20 \%$ of variability in onset of the disease and has a significant influence on reaching nonambulatory status. The analysis indicated that there are other disease modifying factors that influence phenotype. Cohort-specific features expand clinical understanding of the disease and warrant a closer look at the platelet count in GNE patients across the world. Better understanding of the disease progression based on the genotype is important for counselling and management of GNE patients. Potential impact of genotype on the disease progression is also important for clinical trial design and patient stratification. We acknowledge study limitations, such as sample size, and factors (e.g., differences in environment, diet, and health care systems) that can potentially influence the analysis. Therefore, a replication of the analysis on a larger and different cohort would have to be conducted in the future.

\section{Acknowledgment}

The authors would also like to thank GNE myopathy Registry Steering Committee and NDF for supporting this research. This work was supported by European Union Seventh Framework Programme (FP7/2007-2013) under grant agreement No. 305444 (RD-Connect) and Medical Research Council UK (reference G1002274, grant ID 98482).

\section{Study funding}

No targeted funding reported.

\section{Disclosure}

O. Pogoryelova has served as a clinical trial investigator for Ultragenyx Pharmaceutical Inc. I. J. Wilson reports no disclosures. Z. Argov was a consultant for Ultragenyx Pharmaceutical and was Special Medical Advisor for CEO of BioBlast Pharma. The GNE research at Hadassah received grants from AFM, NDF, ISF, and GIF. I. Nishino was an advisor for Ultragenyx Pharmaceutical. The GNE myopathy research is supported currently by Intramural Research Grant (29-4 and 29-3) for Neurological and Psychiatric Disorders of NCNP; AMED under grant numbers JP17ek0109285h0001, JP17ek0109085h0003, JP17ek0109196h0001, and JP17kk0205001s0202; and Health, Labour and Welfare Sciences Research Grants (H29-Nanchito (Nan)-Ippan-030); and was previously by Health, Labour and Welfare Sciences Research Grants, Patients Association for Distal Myopathies, and Neuromuscular Disease Foundation. H. Mansbach is employed and holds stock options with Ultragenyx Pharmaceutical Inc. H. Lochmüller has served as a clinical trial investigator for Ultragenyx Pharmaceutical Inc. Financial support to the Newcastle University and the Newcastle NHS Trust for research projects and clinical trials by AMO Pharmaceuticals, Biogen, GW Pharma, Pfizer, PTC Therapeutics, Roche, and Ultragenyx. Full disclosure form information provided by the authors is available with the full text of this article at Neurology.org/NG.

\section{Publication history}

Received by Neurology: Genetics September 7, 2018. Accepted in final form December 20, 2018.

Appendix 1. Authors contribution

\begin{tabular}{|c|c|c|c|}
\hline Name & Location & Role & Contribution \\
\hline $\begin{array}{l}\text { Oksana } \\
\text { Pogoryelova, } \\
\text { MD, PhD }\end{array}$ & $\begin{array}{l}\text { Institute of Genetic } \\
\text { Medicine, Newcastle } \\
\text { University, } \\
\text { Newcastle upon } \\
\text { Tyne, UK }\end{array}$ & Author & $\begin{array}{l}\text { Design and } \\
\text { conceptualized } \\
\text { study; data } \\
\text { acquisition, analyzed } \\
\text { the data; drafted the } \\
\text { manuscript for } \\
\text { intellectual content. } \\
\text { Member of the GNE } \\
\text { Registry Steering } \\
\text { Committee }\end{array}$ \\
\hline $\begin{array}{l}\text { Ian Wilson, } \\
\text { PhD }\end{array}$ & $\begin{array}{l}\text { Institute of Genetic } \\
\text { Medicine, Newcastle } \\
\text { University, } \\
\text { Newcastle upon } \\
\text { Tyne, UK }\end{array}$ & Author & $\begin{array}{l}\text { Design and } \\
\text { conceptualized } \\
\text { study; analyzed the } \\
\text { data; statistical } \\
\text { analysis; drafted the } \\
\text { manuscript for } \\
\text { intellectual content }\end{array}$ \\
\hline
\end{tabular}


Appendix 1 (continued)

\begin{tabular}{|c|c|c|c|}
\hline Name & Location & Role & Contribution \\
\hline $\begin{array}{l}\text { Hank } \\
\text { Mansbach, } \\
\text { MD }\end{array}$ & $\begin{array}{l}\text { Ultragenyx } \\
\text { Pharmaceutical, CA, } \\
\text { USA }\end{array}$ & Author & $\begin{array}{l}\text { Interpreted the data; } \\
\text { revised the } \\
\text { manuscript for } \\
\text { intellectual content. } \\
\text { Member of the GNE } \\
\text { Registry Steering } \\
\text { Committee }\end{array}$ \\
\hline $\begin{array}{l}\text { Zohar Argov, } \\
\text { MD }\end{array}$ & $\begin{array}{l}\text { Department of } \\
\text { Neurology, } \\
\text { Hadassah-Hebrew } \\
\text { University Medical } \\
\text { Center, Jerusalem, } \\
\text { Israel. }\end{array}$ & Author & $\begin{array}{l}\text { Interpreted the data; } \\
\text { revised the } \\
\text { manuscript for } \\
\text { intellectual content. } \\
\text { Member of the GNE } \\
\text { Registry Steering } \\
\text { Committee }\end{array}$ \\
\hline $\begin{array}{l}\text { Ichizo } \\
\text { Nishino, MD, } \\
\text { PhD }\end{array}$ & $\begin{array}{l}\text { Department of } \\
\text { Neuromuscular } \\
\text { Research, National } \\
\text { Institute of } \\
\text { Neuroscience, } \\
\text { National Center of } \\
\text { Neurology and } \\
\text { Psychiatry, Tokyo, } \\
\text { Japan. }\end{array}$ & Author & $\begin{array}{l}\text { Interpreted the data; } \\
\text { revised the } \\
\text { manuscript for } \\
\text { intellectual content. } \\
\text { Member of the GNE } \\
\text { Registry Steering } \\
\text { Committee }\end{array}$ \\
\hline $\begin{array}{l}\text { Hanns } \\
\text { Lochmuller, } \\
\text { MD, PhD }\end{array}$ & $\begin{array}{l}\text { Children's Hospital of } \\
\text { Eastern Ontario } \\
\text { Research Institute, } \\
\text { University of Ottawa, } \\
\text { Ottawa, Canada and } \\
\text { Division of Neurology, } \\
\text { Department of } \\
\text { Medicine, The Ottawa } \\
\text { Hospital, Ottawa; } \\
\text { Department of } \\
\text { Neuropediatrics and } \\
\text { Muscle Disorders, } \\
\text { Medical Center - } \\
\text { University of Freiburg, } \\
\text { Faculty of Medicine, } \\
\text { Freiburg, Germany; } \\
\text { Centro Nacional de } \\
\text { Análisis Genómico } \\
\text { (CNAG-CRG), Center } \\
\text { for Genomic } \\
\text { Regulation, Barcelona } \\
\text { Institute of Science } \\
\text { and Technology } \\
\text { (BIST), Barcelona, } \\
\text { Catalonia, Spain }\end{array}$ & Author & $\begin{array}{l}\text { Interpreted the data; } \\
\text { revised the } \\
\text { manuscript for } \\
\text { intellectual content. } \\
\text { Member of the GNE } \\
\text { Registry Steering } \\
\text { Committee }\end{array}$ \\
\hline
\end{tabular}

\section{References}

1. Eisenberg I, Avidan N, Potikha T, et al. The UDP-N-acetylglucosamine 2-epimerase/ $\mathrm{N}$-acetylmannosamine kinase gene is mutated in recessive hereditary inclusion body myopathy. Nat Genet 2001;29:83-87.
2. Celeste FV, Vilboux T, Ciccone C, et al. Mutation update for GNE gene variants associated with GNE myopathy. Hum Mutat 2014;35:915-926.

3. Nishino I, Noguchi S, Murayama K, et al. Distal myopathy with rimmed vacuoles is allelic to hereditary inclusion body myopathy. Neurology 2002;59:1689-1693.

4. Argov Z, Eisenberg I, Grabov-Nardini G, et al. Hereditary inclusion body myopathy: the Middle Eastern genetic cluster. Neurology 2003;60:1519-1523.

5. Chamova T, Guergueltcheva V, Gospodinova M, et al. GNE myopathy in Roma patients homozygous for the p.I618T founder mutation. Neuromuscul Disord 2015; 25:713-718.

6. Zhao J, Wang Z, Hong D, et al. Mutational spectrum and clinical features in 35 unrelated mainland Chinese patients with GNE myopathy. J Neurol Sci 2015;354: 21-26.

7. Chaouch A, Brennan KM, Hudson J, et al. Two recurrent mutations are associated with GNE myopathy in the North of Britain. J Neurol Neurosurg Psychiatry 2014;85: 1359-1365.

8. Preethish-Kumar V, Pogoryelova O, Polavarapu K, et al. Beevor's sign: a potential clinical marker for GNE myopathy. Eur J Neurol 2016;23:e46-48.

9. Mori-Yoshimura M, Hayashi YK, Yonemoto N, et al. Nationwide patient registry for GNE myopathy in Japan. Orphanet J Rare Dis 2014;9:150.

10. Haghighi A, Nafissi S, Qurashi A, et al. Genetics of GNE myopathy in the non-Jewish Persian population. Eur J Hum Genet 2016;24:243-251.

11. Noguchi S, Keira Y, Murayama K, et al. Reduction of UDP-N-acetylglucosamine 2-epimerase/ $\mathrm{N}$-acetylmannosamine kinase activity and sialylation in distal myopathy with rimmed vacuoles. J Biol Chem 2004;279:11402-11407.

12. Pogoryelova $\mathrm{O}$, Cammish $\mathrm{P}$, Mansbach $\mathrm{H}$, et al. Phenotypic stratification and genotype-phenotype correlation in a heterogeneous, international cohort of GNE myopathy patients: first report from the GNE Myopathy Disease Monitoring Program, registry portion. Neuromuscul Disord 2018;28:158-168.

13. Team RC. R: A Language and Environment for Statistical Computing. Austria; R Foundation for Statistical Computing Vienna; 2018.

14. Akaike H. A new look at the statistical model identification. IEEE Trans Automatic Control 1974;19:716-723.

15. Relative UG. Importance for linear regression in R: the package relaimpo. J Stat Softw 2006;17:1-27.

16. Venables WN, Ripley BD. Modern Applied Statistics with S-Plus. Berlin, Germany: Springer-Verlag; 1994.

17. Mori-Yoshimura M, Oya Y, Yajima H, et al. GNE myopathy: a prospective natural history study of disease progression. Neuromuscul Disord 2014;24:380-386.

18. Penner J, Mantey LR, Elgavish S, et al. Influence of UDP-GlcNAc 2-epimerase/ ManNAc kinase mutant proteins on hereditary inclusion body myopathy. Biochemistry 2006;45:2968-2977.

19. Eisenberg I, Novershtern N, Itzhaki Z, et al. Mitochondrial processes are impaired in hereditary inclusion body myopathy. Hum Mol Genet 2008;17:3663-3674.

20. Salama I, Hinderlich S, Shlomai Z, et al. No overall hyposialylation in hereditary inclusion body myopathy myoblasts carrying the homozygous M712T GNE mutation. Biochem Biophys Res Commun 2005;328:221-226.

21. Futterer J, Dalby A, Lowe GC, et al. Mutation in GNE is associated with a severe form of congenital thrombocytopenia. Blood 2018;132:1855-1858.

22. Argov Z, Caraco Y, Lau H, et al. Aceneuramic acid extended release administration maintains upper limb muscle strength in a 48-week study of subjects with GNE myopathy: results from a phase 2 , randomized, controlled study. J Neuromuscul Dis 2016;3:49-66.

23. Lochmüller $\mathrm{H}$, Behin $\mathrm{A}$, Caraco $\mathrm{Y}$, et al. A phase 3 randomized study evaluating sialic acid extended-release for GNE myopathy. Neurology Epub 2019 Jan 25.

24. Cho A, Hayashi YK, Monma K, et al. Mutation profile of the GNE gene in Japanese patients with distal myopathy with rimmed vacuoles (GNE myopathy). J Neurol Neurosurg Psychiatry 2014;85:914-917.

25. Mori-Yoshimura M, Monma K, Suzuki N, et al. Heterozygous UDP-GlcNAc 2-epimerase and $\mathrm{N}$-acetylmannosamine kinase domain mutations in the GNE gene result in a less severe GNE myopathy phenotype compared to homozygous $\mathrm{N}$-acetylmannosamine kinase domain mutations. J Neurol Sci 2012;318:100-105.

26. Lu X, Pu C, Huang X, Liu J, Mao Y. Distal myopathy with rimmed vacuoles: clinical and muscle morphological characteristics and spectrum of GNE gene mutations in 53 Chinese patients. Neurol Res 2011;33:1025-1031. 


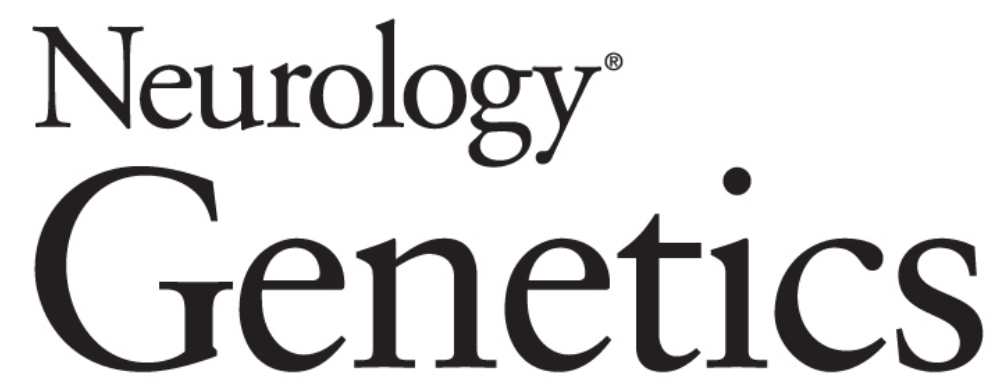

GNE genotype explains $20 \%$ of phenotypic variability in GNE myopathy Oksana Pogoryelova, Ian J. Wilson, Hank Mansbach, et al.

Neurol Genet 2019;5;

DOI 10.1212/NXG.0000000000000308

This information is current as of February 1, 2019

Neurol Genet is an official journal of the American Academy of Neurology. Published since April 2015, it is an open-access, online-only, continuous publication journal. Copyright Copyright ( 2019 The Author(s). Published by Wolters Kluwer Health, Inc. on behalf of the American Academy of Neurology.. All rights reserved. Online ISSN: 2376-7839.

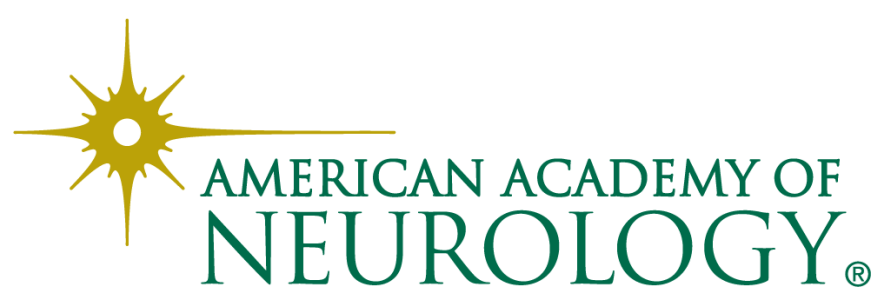




\section{Updated Information \& Services}

References

Citations

Subspecialty Collections

Permissions \& Licensing

Reprints including high resolution figures, can be found at: http://ng.neurology.org/content/5/1/e308.full.html

This article cites 23 articles, 4 of which you can access for free at: http://ng.neurology.org/content/5/1/e308.full.html\#\#ref-list-1

This article has been cited by 1 HighWire-hosted articles: http://ng.neurology.org/content/5/1/e308.full.html\#\#otherarticles

This article, along with others on similar topics, appears in the following collection(s):

\section{All Genetics}

http://ng.neurology.org//cgi/collection/all_genetics

Association studies in genetics

http://ng.neurology.org//cgi/collection/association_studies_in_genetics

Cohort studies

http://ng.neurology.org//cgi/collection/cohort_studies

Muscle disease

http://ng.neurology.org//cgi/collection/muscle_disease

Natural history studies (prognosis)

http://ng.neurology.org//cgi/collection/natural_history_studies_prognos is

Information about reproducing this article in parts (figures,tables) or in its entirety can be found online at:

http://ng.neurology.org/misc/about.xhtml\#permissions

Information about ordering reprints can be found online:

http://ng.neurology.org/misc/addir.xhtml\#reprintsus

Neurol Genet is an official journal of the American Academy of Neurology. Published since April 2015, it is an open-access, online-only, continuous publication journal. Copyright Copyright $\odot 2019$ The Author(s). Published by Wolters Kluwer Health, Inc. on behalf of the American Academy of Neurology.. All rights reserved. Online ISSN: 2376-7839.

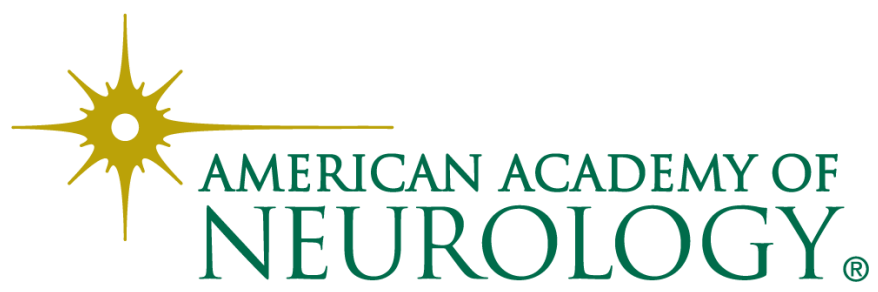

